\title{
Comparison of Students' Marks Between Block and Semester Based Schedules and Its Factors in Introduction to Statistics Course: The Case of Two Departments in Ambo University, 2018/19
}

\author{
Alemayehu Siffir Argawu (MSc.) \\ Ambo University, Department of Statistics, Ambo, Ethiopia
}

\begin{abstract}
An attempt has been made to assess the comparison of students' marks between block and semester based schedules and its factors in introduction to Statistics course in the case of two departments in Ambo University, Ethiopia. In the study, the average mark of the total students was $56.7 \%$ and $69.4 \%$ of semester based scheduled students scored greater than or equal to the average mark but only $45.3 \%$ of block based scheduled students scored greater than or equal to the average mark in introduction to Statistics course assessment. And, From the Chi-square test of association illustrated that variables like schedule type, gender, father's education level, class attending status, group activity participation of 1 to5 and friendship status have significant association with students' marks in introduction to Statistics course. But, religion and region types of the students haven't association with students' marks in the study. Results from the logistic regression uni-variable analysis showed that schedule type, gender, age, father's education, Face book time, grade 12 entrance result, class attendance status, group activity participation of 1 to 5 and friendship status concerning to love were statistically significant factors for students' marks in introduction to Statistics course achievement at 5\% level of significance. And, results from the multi-variables analysis in the logistic regression model indicated that only four out of nine variables like schedule type, student's gender type, grade 12 exam results, and Face book used time were significant factors for students' marks in the course achievement. Ambo University was recommended that introduction to Statistics courses and some other numerical courses should be given by semester based schedule type rather block based schedule. And, curriculum designers in ministry of education need some curriculum changes on the schedule types of some numerically related courses in public universities.
\end{abstract}

Keywords: Students' marks, Schedule types, Binary logistic regression, Ambo University.

DOI: $10.7176 / \mathrm{JEP} / 11-16-05$

Publication date:June 30th 2020

\section{Introduction}

Many researchers determine the quality of university or college student experiences is to examine the effort level students commit in different educational programs. Policy and program changes have an effect on students; an important factor would be to determine if the change(s) creates positive differences in student effort. Any change in the education process is most likely to affect students in some manner (Astin, 2016; Pascarella, 2006; Schwartz \& Tinto, 1987). They have researched the effects that higher education has on students, particularly when examining the effort level exerted by students. In general, the researchers found that faculty to student, student to student, academic involvement and integration leads to positive outcomes for students. Understanding student success factors, and the quality of the college experience, that affect college/university students can help stakeholders make better decisions in designing college programs.

Many studies have addressed the educational benefits and costs of block scheduling though few have documented whether changing the number of times a class meets in a week has any significant effect on learning (Canady \& Rettig, 1995). If colleges reduce the number of times that classes meet to accommodate faculty preferences or to reduce costs, it is possible that student learning could suffer.

Block scheduled class is described as (Davies, 2006) intensive teaching models as "accelerated, time shortened, block format, compressed, or intensive modes of delivery". The author makes the definition of classes taught in the "block mode: very large chunks of teaching time, for example whole day sessions, offered in weeklong mode, two or three week long mode and weekend mode" as stated by (Lawrence and McPherson 2000; Dexter et al., 2006)

The problem addressed by this study was to show how much students' marks were affected by block based schedule rather semester based schedule (traditional schedule) for introduction to Statistics course in two different departments at Ambo University, 2018/19. And, there is no educational researches involving students data to plan which schedules is more appropriate for introduction to Statistics course and other similar numerical courses by comparing block based schedule with traditional based schedule in the University. And, the researcher has a great interest to know the main factors which affect students' marks as stated by (Beyene \& Yimam, 2016; Zewude, 2015). In addition to this, in Ambo university at some colleges there was a problem of 
program schedules in different departments' courses allocation schedules are not based on the nature and the type of the courses. Block based schedule and semester based schedule will be programmed directly related with the nature of the course. So this study will give great information for the university's top managers, college deans, department heads, instructors and also the students. Then, the objective of the study is to compare students' marks between block and semester based schedules in introduction to Statistics course and determines its main factors in the case of two departments at Ambo University, 2018/19.

\section{Method}

\subsection{Study Area}

The study was conducted in Ambo University (AU), West Shoa Zone, Ambo, Oromia, Ethiopia. The target population for this study was AU $1^{\text {st }}$ year $\& 2^{\text {nd }}$ year students in the Departments of Horticulture and Disaster Risk Management and Sustainable Development (DRMSD) in 2018/19 academic year, respectively.

\subsection{Study Design}

The researcher applied a cross section study to collect a data from $1^{\text {st }}$ year students in the department of horticulture in which the students have taken an introduction to Statistics course using block based schedule type and from $2^{\text {nd }}$ year students in the department of disaster risk management and sustainable development (DRMSD) in which students have taken the same course using semester based schedule type in 2018/19 academic year.

\subsection{Sample Size of the Study}

The researcher has taken all students in each department as a sample since the number of the population was not as large. And, the sample size of the study was 113 students from the two departments. 64 of them were from the department of Horticulture in which the students have taken an introduction to Statistics course in the case of block based schedule type, and the remaining 49 students were from the department of DRMSD in which the students have taken the same course in the form of semester base schedule.

\subsection{Data Collection Procedures}

The researcher has collected a primary data from the students in each department after completed the course. The researcher (the instructor) evaluated the students in each department using different continuous assessments when the course was given and at the end of the final exam on second semester of 2018/19 academic year. And, all the continuous assessments and final exam were the same for the two groups. Then, the researcher interested to conduct this research after observing different students' marks between departments. The data was collected using questionnaires at the end of the semester before the students leaving the university, 2018/19.

\subsection{Variables in the Study}

The response variable is "student mark" which has two binary outcomes if the mark $<$ the average value which was coded as 0 and if the mark $\geq$ the average value which was coded as 1 . And, the predictors are schedule type, sex, age, religion, region, father education level, grade 12 entrance result, Face book time, class attendance status, group work participation (1to5), and friendship (love) status.

\subsection{Binary Logistic Regression Model}

Many categorical response variables have only two categories. Denote a binary response variable by $Y$ and its two possible outcomes by 1 ("success") and 0 ("failure"). The distribution of is specified by probabilities:

$P(Y=1)=\pi$ of success and $P(Y=0)=(1-\pi)$ of failure. Its mean is $E(Y)=\pi$. For $\mathrm{n}$ independent observations, the number of successes has the binomial distribution specified by the index $\mathrm{n}$ and parameter $\pi$. The formula was given as $E(Y)=n \pi$ and $\delta=\sqrt{n \pi(1-\pi)}$. Each binary observation is a binomial variate with $n=1$. Although Generalized Linear Models can have multiple explanatory variables, for simplicity we introduce them using a single $\mathrm{x}$.

The value of $\pi$ can vary as the value of $\mathrm{x}$ changes, and $\pi$ is replaced by $\pi(\mathrm{x})$ when we want to describe its dependence on that value. Relationships between $\pi(\mathrm{x})$ and $\mathrm{x}$ are usually nonlinear rather than linear. In the logistic model, the random component for the (success, failure) outcomes has a binomial distribution. The link function is the logit function $\ln [\pi /(1-\pi)]$ of $\pi$, which is defined as the log of odds of success and symbolized by "logit $(\pi)^{\prime \prime}$. Logistics regression models are often called logit models are often called logit models. Whereas $\pi$ is restricted to the range $[0,1]$, the logit can be any real number (Hosmer DW, 2000; Strand \& Winston, 2008). 
Simple Logistic Regression Model:

$$
\ln \left(\frac{\pi(x)}{1-\pi(x)}\right)=\beta_{0}+\beta_{1} X
$$

From equation (1), we deduce:

$$
\begin{gathered}
\frac{\pi(x)}{1-\pi(x)}=e^{\beta_{0}+\beta_{1} X} \\
\pi(x)=e^{\beta_{0}+\beta_{1} X}-\pi(x) e^{\beta_{0}+\beta_{1} X} \\
\pi(x)=\frac{e^{\beta_{0}+\beta_{1} X}}{1+e^{\beta_{0}+\beta_{1} X}}
\end{gathered}
$$

\section{Multiple Logistic Regression Model}

Let us consider the general logistic regression model with multiple explanatory variables. Denote the $\mathrm{k}$ predictors for a binary response $\mathrm{Y}$ by $\mathrm{X}_{1}, \mathrm{X}_{2}, \ldots, \mathrm{X}_{\mathrm{k}}$.

We use $\pi(\mathrm{x})$ to represent the probability that $\mathrm{Y}=1$ for success, and $1-\pi(\mathrm{x})$ to represent the probability that $\mathrm{Y}=$ 0 .

These probabilities are written in the following form:

$$
\begin{aligned}
& \pi(x)=P\left(Y=1 / X_{1}, X_{2}, \ldots, X_{k}\right) \\
& 1-\pi(x)=P\left(Y=0 / X_{1}, X_{2}, \ldots, X_{k}\right)
\end{aligned}
$$

The model for the log odds is:

$$
\begin{aligned}
& \text { logit }(\pi(x))=\ln \frac{P\left(Y=1 / X_{1}, X_{2}, \ldots, X_{k}\right)}{P\left(Y=0 / X_{1}, X_{2}, \ldots, X_{k}\right)} \\
& \text { This gives } \ln \left(\frac{\pi(x)}{1-\pi(x)}\right)=\beta_{0}+\beta_{1} X+\beta_{2} X_{2}+\ldots+\beta_{k} X_{k}+\varepsilon
\end{aligned}
$$

$$
=\beta_{0}+\sum_{j=1}^{k} \beta_{j} X_{j}+\varepsilon
$$

Which yields to:

$$
\pi(x)=P\left(Y=1 / X_{1}, X_{2}, \ldots, X_{k}\right)=\frac{e^{\beta_{0}+\sum_{j=1}^{k} \beta_{j} X_{j}+\varepsilon}}{1+e^{\beta_{0}+\sum_{j=1}^{k} \beta_{j} X_{j}+\varepsilon}}
$$

The parameter $\beta_{j}$ refers to the effect of $X_{j}$ on the log odds that $Y=1$, controlling the other predictor variables. For example, $\exp \left(\beta_{j}\right)$ is the multiplicative effect on the odds of a one-unit increase in $X_{j}$, at fixed level of the other predictor variables.

\section{Results and Discussions}

\subsection{Descriptive Statistics of the Variables}

Most of the variables were investigated using cross tabulations with the dependent variable (student's mark was classified as either $<$ the mean value or $\geq$ the mean value). Another reason for the cross tabulation is to identify categories with small frequencies as this can cause problems with the logistic regression procedure. Table 1 and 2 below showed that the descriptive statistics of the variables (for both categorical and continuous). Thus, the average mark and standard deviation of the students' marks were $56.7 \%$ and $12.5 \%$ with the minimum and maximum marks were $32 \%$ and $90 \%$, respectively. Out of the total of 113 students, majority of the students (63, $55.8 \%$ ) have scored greater than or equal to the average mark and 50(44.2\%) of them have achieved below the average mark. And, majority (69.4\%) of semester based scheduled students scored greater than or equal to the average mark but only $45.3 \%$ of block based scheduled students scored greater than or equal to the average mark in introduction to Statistics course assessment. Similarly, we can see more the other variables descriptive statistics in table 1. 
Table 1: Results of Descriptive Statistics and Test of Association

\begin{tabular}{|c|c|c|c|c|c|c|}
\hline \multirow[t]{2}{*}{ Variables } & \multirow[t]{2}{*}{ Value } & \multicolumn{2}{|l|}{ Mark (100\%) } & \multirow{2}{*}{$\begin{array}{l}\text { Total } \\
(100 \%)\end{array}$} & \multirow[t]{2}{*}{$\chi^{2}$} & \multirow{2}{*}{$\begin{array}{l}\mathrm{P} \text { - } \\
\text { value }\end{array}$} \\
\hline & & $\begin{array}{c}<\text { The average } \\
\text { mark }(56.7)\end{array}$ & $\begin{array}{l}\geq \text { the average } \\
\text { mark }(56.7)\end{array}$ & & & \\
\hline \multirow[t]{3}{*}{ 1. Schedule Type } & Semester based & $15(30.6)$ & $34(69.4)$ & $49(43.4)$ & \multirow[t]{3}{*}{6.52} & \multirow[t]{3}{*}{$0.011 *$} \\
\hline & Block based & $35(54.7)$ & $29(45.3)$ & $64(56.6)$ & & \\
\hline & Total & $50(44.2)$ & $63(55.8)$ & $113(100)$ & & \\
\hline \multirow[t]{2}{*}{ 2. Gender } & Female & $42(75)$ & $14(25)$ & $56(49.6)$ & \multirow[t]{2}{*}{42.6} & \multirow[t]{2}{*}{$0.000 *$} \\
\hline & Male & $8(14)$ & $49(86)$ & $57(50.4)$ & & \\
\hline \multirow[t]{4}{*}{ 3. Religion } & Orthodox & $20(41.7)$ & $28(58.3)$ & $48(42.5)$ & \multirow[t]{4}{*}{3.68} & \multirow[t]{4}{*}{0.298} \\
\hline & Protestant & $20(54.1)$ & $17(45.9)$ & $37(32.7)$ & & \\
\hline & Muslim & $5(27.8)$ & $13(72.2)$ & $18(16)$ & & \\
\hline & Other & $5(50)$ & $5(50)$ & $10(8.8)$ & & \\
\hline \multirow[t]{4}{*}{ 4. Region } & Oromia & $23(44.2)$ & $29(55.8)$ & $52(46)$ & \multirow[t]{4}{*}{0.381} & \multirow[t]{4}{*}{0.944} \\
\hline & Amhara & $14(45.2)$ & $17(54.8)$ & $31(27.4)$ & & \\
\hline & SNNP & $7(38.9)$ & $11(61.1)$ & $18(16)$ & & \\
\hline & Other & $6(50)$ & $6(50)$ & $12(10.6)$ & & \\
\hline \multirow{4}{*}{$\begin{array}{l}\text { 5. Father's } \\
\text { Education Level }\end{array}$} & Illiterate & $8(100)$ & $0(0)$ & $8(7.1)$ & \multirow[t]{4}{*}{43.3} & \multirow[t]{4}{*}{$0.000 *$} \\
\hline & Primary & $15(88.2)$ & $2(11.8)$ & $17(15)$ & & \\
\hline & Secondary & $18(56.3)$ & $14(43.8)$ & $32(28.3)$ & & \\
\hline & $\begin{array}{l}\text { Diploma } \quad \& \\
\text { above }\end{array}$ & $9(16.1)$ & $47(83.9)$ & $56(49.6)$ & & \\
\hline \multirow[t]{2}{*}{ 6. Class Att. Status } & Sometimes & $23(79.3)$ & $6(20.7)$ & $29(25.7)$ & \multirow[t]{2}{*}{19.4} & \multirow[t]{2}{*}{$0.000 *$} \\
\hline & Always & $27(32.1)$ & $57(67.9)$ & $84(74.3)$ & & \\
\hline \multirow{3}{*}{$\begin{array}{l}\text { 7. Group } \\
1 \text { to5 }\end{array}$} & Never & $8(88.9)$ & $1(11.1)$ & $9(8)$ & \multirow[t]{3}{*}{21.2} & \multirow[t]{3}{*}{$0.000^{*}$} \\
\hline & Sometimes & $20(69)$ & $9(31)$ & $29(25.7)$ & & \\
\hline & Always & $22(29.3)$ & $53(70.7)$ & $75(66.3)$ & & \\
\hline \multirow{2}{*}{$\begin{array}{ll}\text { 8. Love } & \text { Friend } \\
\text { Status } & \end{array}$} & No & $17(23.6)$ & $55(76.4)$ & $72(63.7)$ & \multirow[t]{2}{*}{34.3} & \multirow[t]{2}{*}{$0.000 *$} \\
\hline & Yes & $33(80.5)$ & $8(19.5)$ & $41(36.3)$ & & \\
\hline
\end{tabular}

\subsection{Multi-Variables Analysis in the Model}

In this analysis (table 2 below), four variables from nine were statistically significant factors for students' marks in introduction to Statistics course achievement at 5\% level of significance. These were schedule type $(p=0.036$ $<0.05)$, gender $(\mathrm{p}=0.010<0.05)$, grade 12 entrance results $(\mathrm{p}=0.028<0.05)$ and Face book used time $(\mathrm{p}=$ $0.010<0.05)$. Whereas, age of the student, student's father education level, class attendance status, group activity participation ( 1 to 5 ) and friendship status concerning to love were not significant factors.

Table 2: Results of Multi-variables Analysis in Logistic Regression Model

\begin{tabular}{|c|c|c|c|c|c|c|c|c|c|}
\hline \multirow[t]{2}{*}{ Factor } & \multirow[t]{2}{*}{ Value } & \multirow[t]{2}{*}{ B } & \multirow[t]{2}{*}{ SE } & \multirow[t]{2}{*}{ Wald } & \multirow[t]{2}{*}{ DF } & \multirow[t]{2}{*}{$\begin{array}{l}P \text { - } \\
\text { value }\end{array}$} & \multirow[t]{2}{*}{$\operatorname{Exp}(\beta)$} & \multicolumn{2}{|c|}{$\begin{array}{lll}95 \% & \text { CI } & \text { for } \\
\operatorname{Exp}(\beta) & & \end{array}$} \\
\hline & & & & & & & & Lower & Upper \\
\hline 1. Schedule Type & $\begin{array}{l}\text { Semester based } \\
\text { (Ref: Block based) }\end{array}$ & 2.9 & 1.4 & 4.4 & 1 & $0.036^{*}$ & 18.1 & 1.21 & 269.5 \\
\hline 2. Gender & $\begin{array}{l}\text { Female } \\
\text { (Ref: Male) }\end{array}$ & -3.7 & 1.4 & 6.6 & 1 & $0.010 *$ & 0.03 & 0.002 & 0.42 \\
\hline $\begin{array}{l}\text { 3. Grade } 12 \\
\text { result }\end{array}$ & Numeric & 0.2 & 0.1 & 4.8 & 1 & $0.028 *$ & 1.2 & 1.02 & 1.43 \\
\hline $\begin{array}{l}\text { 4. Face book } \\
\text { used time (hr) }\end{array}$ & Numeric & -2.6 & 1.0 & 6.6 & 1 & $0.010 *$ & 0.1 & 0.01 & 0.54 \\
\hline Constant & & - & 24.9 & 4.6 & 1 & 0.031 & 0.00 & & \\
\hline
\end{tabular}

\section{Interpretations of the Odds Ratio}

The odds ratio for significant variables on table 2 above:

- The odd ratio for student who had taken an Introduction to Statistics Course in semester based scheduled was 18.1 times more likely to score greater than or equal to the average point $(56.7 \%)$ than students who had been taught in blocked based schedule.

- The odd ratio for female student was 0.03 times less likely to achieve greater than or equal to the average 
point $(56.7 \%)$ than male student in an Introduction to Statistics Course

- As the student grade 12 entrance result was increased by a one point, then the odd ratio was 1.2 times more likely to score greater than or equal to the average point $(56.7 \%)$ in an Introduction to Statistics Course.

- When the student's face book time was increased by a one hour, then the odd ratio was 0.1 times less likely to attain greater than or equal to the average point $(56.7 \%)$.

\subsection{Discussions of the Results}

Results from multi-variables analysis in logistic regression showed that only four variables like schedule type, gender of the student, grade 12 results and Face book used time were significant factors for students' marks in introduction to Statistics course assessment in the two department of Ambo University.

(Stephanie L. Knight, 1999) reported that students' exam scores were decreased slightly in block schedule format as compare to the traditional method (semester based) which supports the results found in this study. But, (Evans et al., 2002; Zepeda \& Mayers, 2017) analyzed that students' scores were better in block schedule format. Studies by (Alam et al., 2014; Beyene \& Yimam, 2016) found that student's gender type was one of the significant factors in their studies. That is males group scored better than that of female students. And, result found in this study shared those studies reports about student's gender type. These studies also showed that university entrance exam or grade 12 result (past academic track) has influenced the academic performances of a student. Thus, the students' scores increased in the university when the students' university entrance exam results increased by a one point. This study also found that student's grade 12 results is one of the significant factors for students' marks in introduction to Statistics course.

Many researchers found that face book users studied less and got lower grades than non-Face book users which supports the results found in this study that the students' marks were decreased when the students wasted more times on face book (Paul A. Kirschner \& Aryn C. Karpinski, 2009; SZ et al., 2011; Vanden Boogart, 2006). Whereas, other investigators have found that there was no significant relationships between face book usage time and students' scores (Hargittai \& Hsieh, 2010; Sugimoto et al., 2015).

\section{Conclusions and Recommendations}

\subsection{Conclusions}

The main purpose of this study was to compare students' marks between block and semester based schedules in introduction to Statistics course and determines its main factors in the case of two departments at Ambo University, 2018/19. Results from the multi-variables analysis in the logistic regression model showed that only four variables from nine were significant factors at 5\% level of significance. These were schedule type, student's gender type, grade 12 results, and Face book used time were significant factors for students' marks in introduction to Statistics course assessment in the case of two departments at Ambo University, 2018/19. Whereas variables like age of student, father's education level, religion, region, group activity participation 1 to 5 class attending status, and friendship status concerning to love weren't significant factors in model.

\subsection{Recommendations}

* It is recommended that students who have got low results in grade 12 exam results should focus more on their studies in the university.

* It is also suggested that students will decrease using Face book used times since it has indirect correlation coefficient with academic achievement.

* The university's top managers, college deans, department heads and course teachers should give more awareness for female students to give more tutorial classes to achieve their performances more.

* Ambo University was recommended that introduction to Statistics courses and some other numerical courses should be given by semester based schedule type rather block based schedule.

* And, curriculum designers in ministry of education need some curriculum changes on the schedule types of some numerically related courses in public universities.

* Further study with additional predictor variables and including students from different departments in the university has to be made to address the issues raised in this study.

\section{References}

Alam, M. M., Billah, M. A., \& Alam, M. S. (2014). Factors Affecting Academic Performance of Undergraduate Students at International Islamic University Chittagong (IIUC), Bangladesh. Journal of Education and Practice Www.Iiste.Org ISSN 2222-1735 (Paper) ISSN 2222-288X (Online) Vol.5, No.39, 2014, 5, No. 39(December), 143-154.

Astin, A. W. (2016). The Methodology of Research on College Impact, Part Two Author ( $s$ ): Alexander W. Astin Source: Sociology of Education, Vol. 43, No. 4 (Autumn , 1970 ), pp . 437-450 Published by: American Sociological Association Stable URL : http://www.jstor.o. 43(4), 437-450. 
Beyene, K. M., \& Yimam, J. A. (2016). Multilevel Analysis for Identifying Factors Influencing Academic Achievement of Students in Higher Education Institution: The Case of Wollo University. Jouof Education and Practice, 7(13), 17-23.

Canady, R. L, \& Rettig, M. D. (1995). Block scheduling: A catalyst for change in high schools. Princeton, NJ: Eye on Education. 2020.

Davies, W. M. (2006). Intensive teaching formats: A review. Issues in Educational Research, 16(1), 5-22.

Dexter, K. M., Tai, R. H., \& Sadler, P. M. (2006). Traditional and Block Scheduling for College Science Preparation: A Comparison of College Science Success of Students Who Report Different High School Scheduling Plans. The High School Journal, 89(4), 22-33. https://doi.org/10.1353/hsj.2006.0007

Evans, W., Tokarczyk, J., Rice, S., \& McCray, A. (2002). Block Scheduling: An Evaluation of Outcomes and Impact. The Clearing House: A Journal of Educational Strategies, Issues and Ideas, 75(6), 319-323. https://doi.org/10.1080/00098650209603964

Hargittai, E., \& Hsieh, Y. P. (2010). PREDICTORS AND CONSEQUENCES OF DIFFERENTIATED PRACTICES ON SOCIAL NETWORK SITES. Information, Communication \& Society, 13(4), 515-536. https://doi.org/10.1080/13691181003639866

Hosmer DW, L. (2000). Applied Logistic Regression, 2nd ed. New York, USA: John Wiley and Sons.

Lawrence, W. W., \& McPherson, D. D. (2000). A Comparative Study of Block Scheduling and Traditional Scheduling on Academic Achievement. Journal of Instructional Psychology, 27, 178.

Pascarella, E. T. (2006). How college affects students: Ten directions for future research. Journal of College Student Development, 47(5), 508-520. https://doi.org/10.1353/csd.2006.0060

Paul A. Kirschner \& Aryn C. Karpinski. (2009). A description of Face book use and academic performance among undergraduate and graduate students.

Schwartz, S., \& Tinto, V. (1987). Leaving College: Rethinking the Causes and Cures of Student Attrition. Academe, 73(6), 46. https://doi.org/10.2307/40250027

Stephanie L. Knight, N. J. D. L. and R. G. S. S. (1999). Using Multiple Data Sources to Evaluate an Alternative Scheduling Model. University of North Carolina Press, 83(1), 1-13.

Strand, S., \& Winston, J. (2008). Educational aspirations in inner city schools. Educational Studies, 34(4), 249267. https://doi.org/10.1080/03055690802034021

Sugimoto, C., Hank, C., Bowman, T., \& Pomerantz, J. (2015). Friend or faculty: Social networking sites, dual relationships, and context collapse in higher education. First Monday, $20(3$ SE-Articles). https://doi.org/10.5210/fm.v20i3.5387

SZ, S., OMAR, S., BOLONG, J., \& OSMAN, M. (2011). Facebook Addiction Among Female University Students. Uvvg.Ro, 2(7), 96-109. http://www.uvvg.ro/revad/files/nr7/10. sharifah.pdf

Vanden Boogart, M. R. (2006). Uncovering the social impacts of Facebook on a college campus. Counseling and Educational Psychology, Master $\quad$ of, $\quad 131 . \quad$ http://krex.kstate.edu/dspace/bitstream/handle/2097/181/MatthewVandenBoogart2006.pdf?sequence=4

Zepeda, S. J., \& Mayers, R. S. (2017). An Analysis of Research on Block Scheduling Author ( $s$ ): Sally J . Zepeda and R. Stewart Mayers Source: Review of Educational Research, Vol . 76 , No . 1 ( Spring, 2006 ), pp . 137-170 Published by: American Educational Research Association Stable U. 76(1), 137-170.

Zewude, B. T. (2015). Determinants of Academic Performance of Students: Case of Wolaita Sodo University Bereket Tessema Zewude Wolaita Sodo University, College of Natural and Computational Sciences, Department of Statistics, Wolaita Sodo, Ethiopia, P.O. Box 138. 3(4), 35-45. 